\title{
The Effect of IAS-24 Disclosures on Governance Mechanisms and Ownership Structures in Pakistan
}

\author{
Abdul Rafay", Ramla Sadiq** and Mobeen Ajmal ${ }^{* * *}$
}

\begin{abstract}
IAS-24 of the International Financial Reporting Standards focuses on the concept and disclosures of related party transactions (RPTS) for a reporting entity. This study examines the interrelationship between RPTs (as disclosed under IAS24), agency theory, ownership structures and firm performance. Our sample includes nonfinancial companies indexed by the KSE-100 of the Pakistan Stock Exchange during 2006-15. To run the regression models, we determine the regression assumptions, normality, heteroskedasticity, autocorrelation and multicollinearity. We investigate the impact of different RPTs, including cash inflows and outflows, whereas other studies generally look at the impact of RPTs on firm performance in totality. The empirical analysis suggests that institutional ownership has a positive, significant impact on firm performance. Related party purchases have a significant, negative impact on performance, resulting in the expropriation of institutional ownership. RPTs that generate revenues have a significant, positive impact on performance, such that institutional ownership has a propping-up effect with respect to the related parties. In practice, institutional ownership leads to strong corporate governance and contributes to firm performance. While other studies find family ownership responsible for the expropriation effect, we argue that institutional ownership has a propping-up and expropriation effect on related parties. Our study also suggests that certain ownership structures lead to weaker corporate governance mechanisms, resulting in greater agency problems. This, in turn, badly affects company performance and leads to the exploitation of minority shareholders.
\end{abstract}

Keywords: IAS-24, IFRS, related party transactions, ownership structures, conflict of interest, governance.

JEL classification: M40, M41, M49.

\footnotetext{
* Associate professor of finance and accounting, University of Management and Technology, Lahore.

${ }^{* * *}$ Lecturer in finance, University of Management and Technology, Lahore.

*** Lecturer in finance, University of Management and Technology, Lahore.
} 


\section{Introduction}

IAS-24 of the International Financial Reporting Standards (IFRS) defines a related party as a person or entity that is related to the reporting entity preparing its financial statements (see Appendix). A related party transaction (RPT) is the transfer of resources, services or obligations between related parties, regardless of whether a price is charged. A thorough study of RPTs is essential to understand their relationship with corporate performance, which is linked directly to corporate governance mechanisms.

In the long run, the connection between ownership structure, RPTs and performance affects company valuation for prospective investors. This interrelationship needs some investigation because the empirical results show that RPTs lead to efficiency and opportunism (see Cheung, Rau \& Stouraitis, 2006; Jian \& Wong, 2010; Kohlbeck \& Mayhew, 2004; Bertrand, Mehta \& Mullainathan, 2000). RPT disclosure is, therefore, mandatory in financial statements under IAS-24 (see Appendix). These disclosures allow investors to determine the level of interaction between related parties.

The emerging market crisis of $1997 / 98$ showed that ownership structures were fundamental to rerouting cash resources (Jian \& Wong, 2010). Johnson et al. (2000) indicate that controlling stakeholders benefit from asset sales or purchases in the European market. Thus, it becomes necessary to determine the impact of these transactions on firms' financial performance, drawing on earlier studies that examine the incentives underlying corporate decisions to pursue certain types of RPTs (Watts \& Zimmerman, 1986). Several studies show how the volume of RPTs affects earnings management (see DeAngelo, 1988; Jones, 1991; Teoh, Welch \& Wong, 1998a, 1998b) and review its implications for accounting standard setters and regulators (see Healy \& Wahlen, 1999).

While much of the literature looks at the impact of RPTs on company performance in totality, few studies focus on the impact of different types of RPTs, including cash inflows and outflows. The aims of this study are to determine (i) the impact of different types of operational RPTs on firm performance and (ii) if corporate governance mechanisms enhance organizational performance and mitigate agency problems in companies engaged in extensive RPTs. Most studies in this area focus on developed markets, with little or no attention paid to developing markets. 
Our sample consists of nonfinancial companies indexed by the KSE-100 on the Pakistan Stock Exchange. ${ }^{1}$

Our primary research questions are:

- Do RPTs have a significant impact on organizational performance?

- Does ownership structure affect organizational performance?

- Do RPTs affect organizational performance when isolated from ownership structures?

\section{Literature Review}

There are two fundamental results of any RPT: the creation of wealth and the destruction of wealth. The creation of wealth through an RPT is considered an efficient transaction because it indicates that the organization has received a better price against a transaction under firm-specific conditions. Most often, this implies that the parent company can protect the transactions carried out with a subsidiary, transferring some benefits and resources to the firm, which may not have been possible under normal market conditions. As a result, the subsidiary's profitability rises.

The destruction of wealth through an RPT is considered an opportunistic transaction, indicating that the firm's managers place their own interests before those of the firm and the goal of shareholder wealth maximization. This can result in transaction losses, which may not have occurred under normal market conditions. In extreme cases, it may also indicate that the services rendered and assets or financing provided are not charged any price at all, thus resulting in exploitation (Gordon, Henry \& Palia, 2004).

\subsection{RPTs and Minority Shareholders}

Shleifer (2000) argues that RPTs are used to divert resources from the corporation to majority shareholders. This is considered an opportunistic transaction and takes place under specific ownership structures. Examples include, but are not limited to, transfer pricing that favors shareholders, the transfer of assets to controlling shareholders at nonmarket prices and the use of assets as collateral for loans. When a firm is involved in such transactions through a parent company, partnership or

\footnotetext{
${ }^{1}$ Formerly known as the Karachi Stock Exchange.
} 
joint venture, it reaps benefits that would not have come about under fair market conditions.

RPTs involve the transfer of an advantage from the company to its majority shareholders, sometimes at the expense of minority shareholders (Friedman, Johnson \& Mitton, 2003). They can be used to relocate wealth or capital from the company to the controlling managers and executives, thereby putting minority shareholders at a disadvantage (La Porta et al., 2000). In the case of China, Jian and Wong (2010) find that resources are diverted through RPTs in approximately 90 percent of listed firms.

The firm's ownership structure plays a significant role in the degree of exploitation (Jensen \& Meckling, 1976). When investors understand how minority shareholders can be exploited in this way, the average investor is likely to assign a lower market value to firms that employ RPTs (Jian \& Wong, 2010; Cheung et al., 2009). Cheung et al. (2006) point to the greater likelihood of negative returns as well as lower abnormal returns when internal mechanisms are used to exploit the firm's resources, ultimately harming its minority shareholders.

\subsection{RPTs, Agency Theory and Ownership Structures}

While ownership structures play a significant role in efficient RPTs, agency theory implies that, in the absence of oversight, executives have a chance to expropriate the firm's funds, leading to a fundamental conflict of interest. Maury (2006) identifies two forms of agency conflict:

- Type I: Classic principal-agent conflict between the firm's owner and manager

- Type II: Conflict between the firm's controlling family and manager.

Type I agency conflicts do not arise in family-owned organizations, which tend to have strong mechanisms in place to monitor firm managers. Family-owned firms are also characterized by better incentive packages for managers. Organizations with high levels of family ownership are more likely to face expropriation due to RPTs (Morck \& Yeung, 2003), which ultimately benefit the controlling family (Gordon et al., 2007; Louwers et al., 2008). The traditional type I agency problem is thus associated with institutional, rather than family, ownership.

When RPTs are used to help firms in financial distress, the pattern of shareholding in group companies determines the extent of the agency 
problem. Riyanto and Toolsema (2008) argue that a group company's decision to use RPTs to support subordinate firms benefits the former. Berle and Means (1991) and Jensen and Meckling (1976) find that arm'slength transactions create a conflict between agent and owner.

Family-owned firms also face lower agency costs and are likely to have a better grasp of their particular business (Klein, 2002; Maury, 2006; Villalonga \& Amit, 2006). This implies that such firms perform better in the context of RPTs (Anderson \& Reeb, 2003; Villalonga \& Amit, 2006; Maury, 2006; Siregar \& Utama, 2008). This benefits minority shareholders because lower agency costs and better corporate governance practices increase the profitability of the firm (Larcker, Richardson \& Tuna, 2007). A growing body of research focuses on the possible expropriation of funds by large shareholders (see, for example, Bae, Kang \& Kim, 2002; Bebchuk, Kraakman \& Triantis, 2000; Johnson et al., 2000). Most of these studies concentrate on the market valuation effects of ownership structures (see Bae et al., 2002; Claessens et al., 2002).

\subsection{Efficient RPTs, Profitability and Earnings Management}

Efficient RPTs are those that enable efficient resource use between holding companies and subsidiaries (Coase, 1937; Williamson, 1983). This refers to transactions that may not have occurred under general market conditions, but become possible with the additional resources and expertise provided by related parties. Such transactions are likely to lead to better performance and higher levels of profitability.

Although most studies analyze RPTs as a single, summarized variable, the indication of profitability makes it necessary to segregate the types of RPTs to determine which specific transactions are more efficient (Gordon et al., 2004). Jian and Wong (2010) find that Chinese companies engaged in RPTs support their associated companies by offering more trade credit and lending to related parties. The net effect is that of wealth maximization for shareholders due to better access to financing. Similarly, a study of S\&P 500 companies finds that the incidence of borrowing from related parties is lowest, while that of loans to directors, executives and controlling owners is highest (Kohlbeck \& Mayhew, 2004). Another study shows that controlling owners shift resources from organizations with high profits to those with lower cash flows to prop up firm performance (Jaggi, Leung \& Gul, 2009). 
Few studies have investigated RPTs as a means of earnings management and their impact on seasoned companies versus new issuers. Aharony, Wang and Yuan (2010) explain that RPTs enable companies to expropriate and increase their earnings prior to the initial public offering (IPO) period. However, this strategy results in post-IPO losses, indicating that RPTs have a negative impact on IPOs in the long term. In considering financial RPTs (those involving loans and loan markups), the research shows that companies tend to provide loans to their subsidiaries, in which scenario, holding companies perform poorly and have a greater likelihood of being delisted (Jiang, Lee \& Yue, 2008).

Synergy and value maximization is important in emerging markets with capital constraints and prone to economic or financial instability. Small firms in emerging markets may face information asymmetries and inaccurate evaluations. Risk-averse investors tend to invest in large, stable firms that have, historically, performed well (Gopalan, Nanda \& Seru, 2007; Shin \& Park, 1999). Group affiliated corporations benefit from group membership when financial resources are shared with other member corporations (Chang \& Hong, 2000). Equity investment and internal trade are widely used for cross-subsidization purposes (Khanna, 2000; Khanna \& Palepu, 2000). This effectively indicates that RPTs can lead to value maximization in an otherwise unfavorable environment.

\section{Research Methodology}

The data for this study was drawn from the annual reports of 78 nonfinancial companies indexed by the Pakistan Stock Exchange's KSE-100 over the period 2006-15.

\subsection{Variables}

The return on total assets (ROA) is used to measure organizational performance - the dependent variable. ROA is the proportion of net income to the total book value of assets. In order to determine which type of RPT has the greatest impact on organizational performance, we select five operational RPT variables: two for related party inflows and three for related party outflows. These are constructed based on the prevalent transactions in the sample and in accordance with IAS-24 classification. Related party inflows include:

- $\quad$ Related party sales (RpSale): all sales of goods made to related parties.

- $\quad$ Related party revenues (RpRev): all services provided to related parties. 
Related party outflows include:

- Related party donations (RpDon): donations made to an organization in which the directors or their immediate family members have any interest.

- Related party purchases (RpPur): all purchases of goods from related parties.

- Related party expenses (RpExp): all expenses incurred by services provided by related parties.

Four variables are used to determine the impact of ownership structure on RPTs. Each variable is calculated as the party's relevant proportion of ownership relative to total shares:

- Public shareholding (ShInd): shares held by the public / total shares.

- Institutional shareholding (ShInst): shares held by institutions / total shares.

- Executive and family shareholding (ShDFam): shares held by directors, executives and their family members / total shares.

- Associated companies' shareholding (ShACo): shares held by associated companies / total shares.

The four control variables include:

- Audit quality $(A u d)$ : a dummy variable equal to 1 when the company's external auditor is one of the Big Four, and 0 otherwise. This controls for basic corporate governance attributes.

- Board independence (Inboard): the ratio of independent directors to total directors, to control for basic corporate governance attributes.

- Leverage (Lev): the ratio of total debt to total assets, to control for the different leverage of companies.

- Company size (Size): the log of total assets, to control for the variation in company size.

\subsection{Empirical Model}

Running a simple ordinary least squares (OLS) regression requires checking for the associated assumptions of normality, heteroskedasticity, autocorrelation and multicollinearity. The OLS model is: 


$$
\begin{aligned}
\text { ROA }_{i}=\propto_{0}+\propto_{1} & \text { Lev }_{i t}+\propto_{2} \text { Size }_{i t}+\propto_{3} \text { Aud }_{i t}+\propto_{4} \text { Inboard }_{i t}+\propto_{5} \text { ShInd }_{i t} \\
& +\propto_{6} \text { ShInst }_{i t}+\propto_{6} \text { ShDFam }_{i t}+\propto_{6} \text { ShACo }_{i t}+\beta_{1} \text { RpRev }_{i t} \\
& +\beta_{2} \text { RpSale }_{i t}+\beta_{3} \text { RpPur }_{i t}+\beta_{4} \text { RpExp }_{i t}+\beta_{5} \text { RpDon }_{i t}+\varepsilon_{i}
\end{aligned}
$$

However, a two-stage least squares (2SLS) model is more appropriate because good corporate governance would deter organizations from using RPTs opportunistically or exploiting minority shareholders. Logically, poor corporate governance would foster an environment in which RPTs could be used by other organizations to benefit at the expense of the subject organization.

$$
\begin{gathered}
\text { ROA }_{i}=\propto_{0}+\propto_{1} \text { Lev }_{i t}+\propto_{2} \text { Size }_{i t}+\propto_{3} \text { Aud }_{i t}+\propto_{4} \text { Inboard }_{i t}+\propto_{5} \text { ShInd }_{i t} \\
+\propto_{6} \text { ShInst }_{i t}+\propto_{6} \text { ShDFam }_{i t}+\propto_{6} \text { ShACo }_{i t}+\varepsilon_{i}
\end{gathered}
$$

The first equation attempts to determine which part of ROA is explained by corporate governance and shareholding patterns. Thus, stronger corporate governance and optimal, efficient shareholding patterns should explain a portion of the returns. The error term is the idiosyncratic portion that is not affected by good corporate governance practices and is referred to as noncorporate governance ROA or NROA. The second step is to regress the error (NROA) on the RPT variables:

$$
\begin{aligned}
\mathrm{NROA}_{i}=\beta_{0}+ & \beta_{1} \text { RpRev }_{i t}+\beta_{2} \text { RpSale }_{i t}+\beta_{3} \text { RpPur }_{i t}+\beta_{4} \text { RpExp }_{i t} \\
& +\beta_{5} \text { RpDon }_{i t}+\gamma_{i}
\end{aligned}
$$

This step determines whether the portion of ROA that is not explained by good corporate governance practices is affected by RPTs. Thus, we would expect $\beta_{1}$ and $\beta_{2}$ to be positive and significant and $\beta_{3}, \beta_{4}$ and $\beta_{5}$ to be negative. This would explain how RPTs supersede the firm's corporate governance practices and positively or negatively affect the firm. If all the $\beta_{i}$ variables are 0 , this would indicate that the organization is not using RPTs to benefit from, or to support, any other organization. To account for heteroskedasticity, we use robust standard errors to correct the model's parameter estimates for heteroskedasticity.

\section{Results}

Table 1 gives the summary statistics for the variables of interest. Over the period of 10 years, organizations earned a return of 14.80 percent on average, with a standard deviation of 20.82 percent. To resolve the problem of scaling, the variables are expressed as logs or as percentages. 
Structures in Pakistan

Table 1: Summary statistics

\begin{tabular}{lcrrrc}
\hline Variable & Observations & Mean & \multicolumn{1}{c}{ SD } & Min & Max \\
\hline ROA & 3,516 & 14.80 & 20.82 & -17.03 & 86.50 \\
Size & 3,516 & 15.74 & 1.78 & 12.32 & 17.84 \\
Inboard & 3,516 & 13.88 & 10.64 & 0.00 & 32.85 \\
ShInd & 3,516 & 23.62 & 19.44 & 1.89 & 65.12 \\
ShInst & 3,516 & 11.24 & 12.56 & 0.00 & 61.74 \\
ShDFam & 3,516 & 16.99 & 23.33 & 0.00 & 82.64 \\
ShAco & 3,516 & 39.42 & 31.98 & 0.00 & 88.25 \\
RpRev & 3,516 & 4.11 & 5.74 & 0.00 & 14.80 \\
RpSales & 3,516 & 6.56 & 5.65 & 0.00 & 19.36 \\
RpPur & 3,516 & 6.95 & 6.25 & 0.00 & 18.95 \\
RpExp & 3,516 & 6.88 & 5.62 & 0.00 & 18.99 \\
RpDon & 3,516 & 1.71 & 3.64 & 0.00 & 14.45 \\
\hline
\end{tabular}

Source: Authors' calculations.

Table 2 captures the correlation among the variables. As expected, there is a high negative correlation between leverage and ROA, indicating an inverse relationship between leverage and firm performance. Organizations with higher levels of related party sales also have more related party purchases and similar operational RPTs. Firms with related party expenses tend to have higher levels of related party donations. 


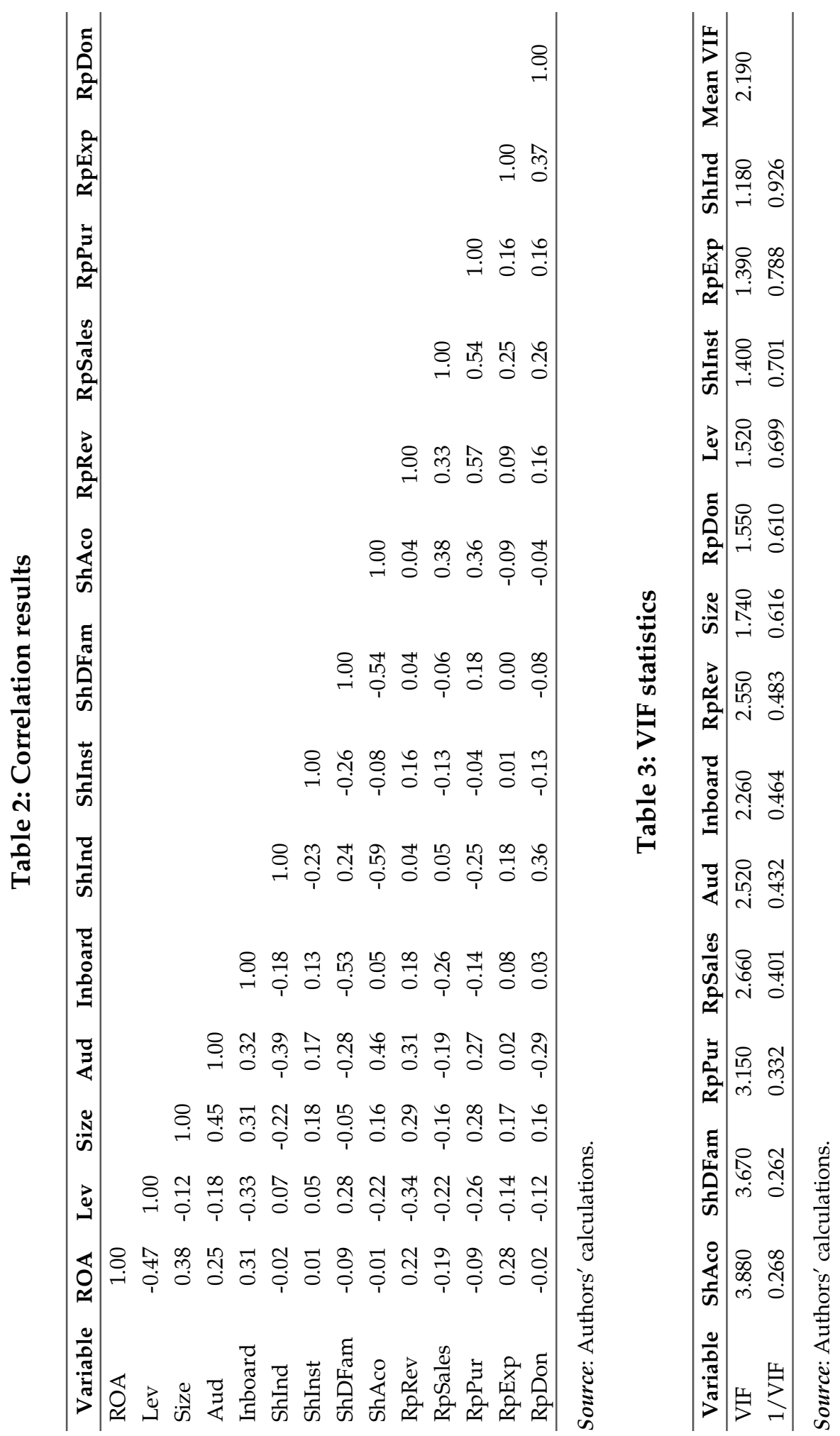


The high correlations suggest there may be multicollinearity in the data and that we have added certain explanatory variables unnecessarily. However, the variance inflation factors (VIFs) in Table 3 are all less than 10 , which means there is no multicollinearity in the independent variables. Table 4 gives the results of the simple OLS regression and shows that all the assumptions of linear regression hold. The Shapiro-Francia statistic suggests that the data is normal. The Durbin-Watson test shows there is no autocorrelation in the data. The Breusch-Pagan test confirms linear homoskedasticity and White's test establishes general homoskedasticity (see Gujarati, Porter \& Gunasekar, 2009).

\section{Table 4: Overall regression analysis}

\begin{tabular}{|c|c|c|c|c|c|c|}
\hline ROA & Coefficient & SE & $\mathrm{T}$ & $P>t$ & \multicolumn{2}{|c|}{ [95\% Conf. interval] } \\
\hline Lev & -0.1492 & 0.0702 & -2.1428 & $0.0425^{*}$ & -0.2832 & -0.0121 \\
\hline Size & 0.0061 & 0.0975 & 0.0682 & 0.9526 & -0.1923 & 0.2056 \\
\hline Aud & -0.0095 & 0.4326 & -0.0229 & 0.9901 & -0.8696 & 0.8562 \\
\hline Inboard & 1.3294 & 1.8288 & 0.7269 & 0.4706 & -2.3102 & 4.9582 \\
\hline ShInd & 0.0001 & 0.0003 & 0.5720 & 0.5732 & -0.0002 & 0.0005 \\
\hline ShInst & 0.0419 & 0.0134 & 3.3263 & $0.0016^{*}$ & 0.0174 & 0.0656 \\
\hline ShDFam & 0.0172 & 0.0121 & 1.4574 & 0.1511 & -0.0065 & 0.0382 \\
\hline ShAco & 0.0075 & 0.0083 & 0.7801 & 0.4623 & -0.0092 & 0.0231 \\
\hline RpRev & 0.0444 & 0.0210 & 2.1733 & $0.0326^{*}$ & 0.0045 & 0.0854 \\
\hline RpSales & 0.0196 & 0.0396 & 0.4838 & 0.6425 & -0.0586 & 0.0935 \\
\hline RpPur & -0.0536 & 0.0223 & -2.4569 & $0.0171^{*}$ & -0.0949 & -0.0109 \\
\hline RpExp & 0.0229 & 0.0290 & 0.7886 & 0.4625 & -0.0336 & 0.0756 \\
\hline RpDon & -0.0367 & 0.0191 & -2.0426 & $0.0503^{*}$ & -0.0726 & -0.0003 \\
\hline Constant & -0.6756 & 1.4039 & -0.4826 & 0.6364 & -3.4739 & 2.1162 \\
\hline \multicolumn{4}{|c|}{ Observations } & \multicolumn{2}{|c|}{3,516} & \\
\hline \multicolumn{4}{|c|}{ R-squared } & \multicolumn{2}{|c|}{0.2572} & \\
\hline \multicolumn{4}{|l|}{ Prob. $>$ F } & \multicolumn{2}{|c|}{0.0495} & \\
\hline \multicolumn{4}{|c|}{ Shapiro-Francia normality test } & \multicolumn{2}{|c|}{$\begin{array}{l}0.9671 \\
p=0.066622\end{array}$} & \\
\hline \multicolumn{4}{|c|}{ Durbin-Watson test } & \multicolumn{2}{|c|}{$\begin{array}{l}2.285 \\
p=0.004601\end{array}$} & \\
\hline \multicolumn{4}{|c|}{ Breusch-Pagan test } & \multicolumn{2}{|c|}{$\begin{array}{l}0.9102 \\
p=0.3512\end{array}$} & \\
\hline \multicolumn{4}{|c|}{ White's general test for heteroskedasticity } & \multicolumn{2}{|c|}{$\begin{array}{l}10.54 \\
p=0.0699\end{array}$} & \\
\hline
\end{tabular}

Note: ${ }^{*}=$ significant at $5 \%$ level.

Source: Authors' calculations. 
The model predicts that leverage and institutional shareholding as well as related party revenues, purchases and donations have a significant impact on ROA. As expected, related party revenues have a positive effect on ROA, while donations and purchases have a negative impact on ROA. A 1 percent increase in related party revenues is expected to increase ROA by 4.44 percent, while a 1 percent increase in related party purchases will decrease ROA by 5.36 percent. This suggests that RPTs do affect returns. The positive impact of RPTs indicates efficient transactions, which is in accordance with the literature (see Coase, 1937; Williamson, 1983; Jian \& Wong, 2010; Jaggi et al., 2009).

A 2SLS model is used to judge the effectiveness of corporate governance and shareholding structures on related party dynamics. Table 5 shows that two corporate governance variables affect firm performance. The larger the number of independent members of the board, the better the firm will perform.

Table 5: Regression analysis of corporate governance

\begin{tabular}{lccclcr}
\hline ROA & Coefficient & SE & T & P > t & \multicolumn{2}{c}{ [95\% Conf. interval] } \\
\hline Lev & -0.162 & 0.064 & -2.149 & $0.042^{*}$ & -0.302 & -0.013 \\
Size & -0.027 & 0.095 & -0.276 & 0.8 .1 & -0.215 & 0.161 \\
Aud & 0.126 & 0.362 & 0.323 & 0.769 & -0.598 & 0.813 \\
Inboard & 1.921 & 0.619 & 3.056 & $0.004^{*}$ & 0.669 & 3.075 \\
ShInd & 0.000 & 0.000 & 0.322 & 0.777 & 0.000 & 0.000 \\
ShInst & 0.038 & 0.013 & 3.478 & $0.001^{*}$ & 0.018 & 0.072 \\
ShDFam & 0.012 & 0.009 & 1.396 & 0.184 & -0.005 & 0.039 \\
ShAco & 0.003 & 0.008 & 0.357 & 0.764 & -0.016 & 0.018 \\
Constant & -0.173 & 1.264 & -0.143 & 0.902 & -2.684 & 2.333 \\
\hline Observations & \multicolumn{7}{c}{107} & & & & \\
R-squared & 0.1866 & & & & \\
Prob. $>$ F & 0.0371 & & & & \\
\hline
\end{tabular}

Source: Authors' calculations.

An increase in institutional shareholding affects firm performance positively. This indicates the propping-up effect of ownership structures on company performance, which contravenes the results of earlier research. Most other studies find that family ownership tends to lead to efficient transactions (see Anderson \& Reeb, 2003; Villalonga \& Amit, 2006; Maury, 2006; Riyanto \& Toolsema, 2008; Siregar \& Utama, 2008), while institutional ownership leads to opportunism (Bae et al., 2002; Bebchuk et al., 2000; Johnson et al., 2000). 
Related party revenues and purchases are still significant in this model (Table 6). Donations are not significant, but expenses are significant at 10 percent. This shows that RPTs affect firm performance over and above the effect of a normal transaction. While donations were significant in the 1SLS model, they are no longer so in the 2SLS model. This finding is also unique to our study, especially considering the decomposition of the RPT variables. While RPT donations appear to be significant for the overall sample, isolating the impact of ownership structures renders the former insignificant.

Table 6: Regression analysis of performance and RPTs

\begin{tabular}{lccclcc}
\hline \multicolumn{1}{c}{ NROA } & Coefficient & SE & T & P > t & \multicolumn{2}{c}{ [95\% Conf. interval] } \\
\hline RpRev & 0.192 & 0.075 & 2.744 & $0.008^{*}$ & 0.058 & 0.335 \\
RpSales & -0.029 & 0.091 & -0.245 & 0.824 & -0.222 & 0.176 \\
RpPur & -0.089 & 0.049 & -2.436 & $0.019^{*}$ & -0.186 & -0.019 \\
RpExp & 0.131 & 0.072 & 1.892 & $0.069^{* *}$ & -0.009 & 0.260 \\
RpDon & 0.098 & 0.109 & 0.925 & 0.371 & -0.116 & 0.321 \\
Constant & -2.603 & 0.536 & -4.932 & $0.000^{*}$ & -3.665 & -1.584 \\
\hline Observations & 3,516 & & & & \\
R-squared & 0.1544 & & & & \\
Prob. $>$ F & 0.0051 & & & & & \\
\hline
\end{tabular}

Note: ${ }^{* *}=$ significant at $10 \%$ level.

Source: Authors' calculations.

Similarly, board independence and institutional shareholding deter unnecessary donations to firms in which the directors hold an interest. However, this does not deter the purchase pattern in the sample companies, suggesting vertical integration. Transparent borders do not allow arm'slength transactions and thus have a negative impact on firm performance.

\section{Conclusion}

This study was conducted to investigate the interrelationship among RPTs, agency theory, ownership structures and firm performance. The empirical analysis reveals that institutional ownership has a positive, significant impact on organizational performance because it is associated with strong corporate governance practices.

While most other studies identify family ownership as the culprit in cases of expropriation, we argue that institutional ownership has a specific role to play, in which regard RPTs explain the variation or residual 
effect. Related party purchases have a negative and significant impact on organizational performance, with an expropriation effect under institutional ownership on related parties. RPTs that generate revenues have a positive and significant impact on organizational performance, which props up the effect of institutional ownership on related parties.

The policy implications of this are relevant to company executives, policymakers and shareholders. The study shows that company executives can develop policies to prop up companies and enhance firm performance. This means that firms in emerging economies should focus on RPT revenues and RPT expenses with higher levels of institutional ownership. Policymakers should focus on the prevalence of expropriation in familyowned firms through RPT purchases. Limiting the volume or frequency of RPT purchases could help curtail the exploitation of minority shareholders. For investors, the study provides additional information that may help them determine if RPTs are likely to lead to expropriation. Specifically, investors should remain wary of family-owned firms characterized by a high volume of RPTs, which could result in smaller returns. 


\section{References}

Aharony, J., Wang, J., \& Yuan, H. (2010). Tunneling as an incentive for earnings management during the IPO process in China. Journal of Accounting and Public Policy, 29(1), 1-26.

Anderson, R. C., \& Reeb, D. M. (2003). Founding-family ownership and firm performance: Evidence from the S\&P 500. The Journal of Finance, 58(3), 1301-1328.

Bae, K.-H., Kang, J.-K., \& Kim, J.-M. (2002). Tunneling or value added? Evidence from mergers by Korean business groups. The Journal of Finance, 57(6), 2695-2740.

Bebchuk, L. A., Kraakman, R., \& Triantis, G. (2000). Stock pyramids, crossownership and dual class equity: The mechanisms and agency costs of separating control from cash-flow rights. In R. K. Morck (Ed.), Concentrated corporate ownership (pp. 295-318). Chicago, IL: University of Chicago Press.

Berle, A. A., \& Means, G. C. (1991). The modern corporation and private property. New Brunswick, NJ: Transaction Publishers.

Bertrand, M., Mehta, P., \& Mullainathan, S. (2000). Ferreting out tunneling: An application to Indian business groups (Working Paper No. 7952). Cambridge, MA: National Bureau of Economic Research.

Chang, S. J., \& Hong, J. (2000). Economic performance of group-affiliated companies in Korea: Intragroup resource sharing and internal business transactions. Academy of Management Journal, 43(3), 429-448.

Cheung, Y.-L., Qi, Y., Rau, P. R., \& Stouraitis, A. (2009). Buy high, sell low: How listed firms price asset transfers in related party transactions. Journal of Banking and Finance, 33(5), 914-924.

Cheung, Y.-L., Rau, P. R., \& Stouraitis, A. (2006). Tunneling, propping and expropriation: Evidence from connected party transactions in Hong Kong. Journal of Financial Economics, 82(2), 343-386.

Claessens, S., Djankov, S., Fan, J. P., \& Lang, L. H. (2002). Disentangling the incentive and entrenchment effects of large shareholdings. The Journal of Finance, 57(6), 2741-2771. 
Coase, R. H. (1937). The nature of the firm. Economica, 4(16), 386-405.

DeAngelo, L. E. (1988). Managerial competition, information costs and corporate governance: The use of accounting performance measures in proxy contests. Journal of Accounting and Economics, 10(1), 3-36.

Friedman, E., Johnson, S., \& Mitton, T. (2003). Propping and tunneling. Journal of Comparative Economics, 31(4), 732-750.

Gopalan, R., Nanda, V., \& Seru, A. (2007). Affiliated firms and financial support: Evidence from Indian business groups. Journal of Financial Economics, 86(3), 759-795.

Gordon, E. A., Henry, E., Louwers, T. J., \& Reed, B. J. (2007). Auditing related party transactions: A literature overview and research synthesis. Accounting Horizons, 21(1), 81-102.

Gordon, E. A., Henry, E., \& Palia, D. (2004). Related party transactions and corporate governance. In M. Hirschey, K. John \& A. K. Makhija (Eds.), Corporate governance (Advances in financial economics, vol. 9, pp. 1-27). Bingley, UK: Emerald Group Publishing.

Gujarati, D. N., Porter, D. C., \& Gunasekar, S. (2009). Basic econometrics. New Delhi: Tata McGraw-Hill Education.

Healy, P. M., \& Wahlen, J. M. (1999). A review of the earnings management literature and its implications for standard setting. Accounting Horizons, 13(4), 365-383.

Jaggi, B., Leung, S., \& Gul, F. (2009). Family control, board independence and earnings management: Evidence based on Hong Kong firms. Journal of Accounting and Public Policy, 28(4), 281-300.

Jensen, M. C., \& Meckling, W. H. (1976). Theory of the firm: Managerial behavior, agency costs and ownership structure. Journal of Financial Economics, 3(4), 305-360.

Jian, M., \& Wong, T. J. (2010). Propping through related party transactions. Review of Accounting Studies, 15(1), 70-105. 
Jiang, G., Lee, C., \& Yue, H. (2008). Tunneling in China: The remarkable case of inter-corporate loans. Unpublished manuscript. Retrieved from http://www.haas.berkeley.edu/groups/finance/JLY_080530.pdf

Johnson, S., La Porta, R., Lopez-De-Silanes, F., \& Shleifer, A. (2000). Tunneling. American Economic Review, 90(2), 22-27.

Jones, J. J. (1991). Earnings management during import relief investigations. Journal of Accounting Research, 29(2), 193-228.

Khanna, T. (2000). Business groups and social welfare in emerging markets: Existing evidence and unanswered questions. European Economic Review, 44(4-6), 748-761.

Khanna, T., \& Palepu, K. (2000). Is group affiliation profitable in emerging markets? An analysis of diversified Indian business groups. The Journal of Finance, 55(2), 867-891.

Klein, A. (2002). Audit committee, board of director characteristics and earnings management. Journal of Accounting and Economics, 33(3), 375-400.

Kohlbeck, M. J., \& Mayhew, B. W. (2004, September). Related party transactions. Paper prepared for the 2005 American Accounting Association FARS Meeting.

La Porta, R., Lopez-de-Silanes, F., Shleifer, A., \& Vishny, R. (2000). Investor protection and corporate governance. Journal of Financial Economics, $58(1-2), 3-27$.

Larcker, D. F., Richardson, S. A., \& Tuna, I. (2007). Corporate governance, accounting outcomes and organizational performance. The Accounting Review, 82(4), 963-1008.

Louwers, T. J., Henry, E., Reed, B. J., \& Gordon, E. A. (2008). Deficiencies in auditing related party transactions: Insights from AAERs. Current Issues in Auditing, 2(2), A10-A16.

Maury, B. (2006). Family ownership and firm performance: Empirical evidence from Western European corporations. Journal of Corporate Finance, 12(2), 321-341. 
Morck, R., \& Yeung, B. (2003). Agency problems in large family business groups. Entrepreneurship Theory and Practice, 27(4), 367-382.

Riyanto, Y. E., \& Toolsema, L. A. (2008). Tunneling and propping: A justification for pyramidal ownership. Journal of Banking and Finance, 32(10), 2178-2187.

Shin, H.-H., \& Park, Y. S. (1999). Financing constraints and internal capital markets: Evidence from Korean 'chaebols'. Journal of Corporate Finance, 5(2), 169-191.

Shleifer, A. (2000). Inefficient markets: An introduction to behavioral finance. New York: Oxford University Press.

Siregar, S. V., \& Utama, S. (2008). Type of earnings management and the effect of ownership structure, firm size and corporate-governance practices: Evidence from Indonesia. International Journal of Accounting, 43(1), 1-27.

Teoh, S. H., Welch, I., \& Wong, T. J. (1998a). Earnings management and the long-run market performance of initial public offerings. The Journal of Finance, 53(6), 1935-1974.

Teoh, S. H., Welch, I., \& Wong, T. J. (1998b). Earnings management and the underperformance of seasoned equity offerings. Journal of Financial Economics, 50(1), 63-99.

Villalonga, B., \& Amit, R. (2006). How do family ownership, control and management affect firm value? Journal of Financial Economics, 80(2), 385-417.

Watts, R. L., \& Zimmerman, J. L. (1986). Positive accounting theory. Englewood Cliffs, NJ: Prentice Hall Inc.

Williamson, O. E. (1983). Markets and hierarchies: Analysis and antitrust implications. Glencoe, IL: The Free Press. 


\section{Appendix}

\section{Who are related parties? (as per IAS-24 of the IFRS) ${ }^{2}$}

A related party is a person or entity that is related to the entity preparing its financial statements (referred to as the 'reporting entity').

(a) A person or a close member of that person's family is related to a reporting entity if that person:

- Has control or joint control over the reporting entity

- Has significant influence over the reporting entity

- Is a member of the key management personnel of the reporting entity or of a parent of the reporting entity.

(b) An entity is related to a reporting entity if any of the following conditions applies:

- The entity and the reporting entity are members of the same group (which means that each parent, subsidiary and fellow subsidiary is related to the others).

- One entity is an associate or joint venture of the other entity (or an associate or joint venture of a member of a group of which the other entity is a member).

- Both entities are joint ventures of the same third party.

- One entity is a joint venture of a third entity and the other entity is an associate of the third entity.

- The entity is a post-employment defined benefit plan for the benefit of employees of either the reporting entity or an entity related to the reporting entity. If the reporting entity is itself such a plan, the sponsoring employers are also related to the reporting entity.

- The entity is controlled or jointly controlled by a person identified in (a).

- A person identified in (a)(i) has significant influence over the entity or is a member of the key management personnel of the entity (or of a parent of the entity).

${ }^{2} \mathrm{http}: / /$ www.iasplus.com/en/standards/ias/ias24 
- The entity, or any member of a group of which it is a part, provides key management personnel services to the reporting entity or to the parent of the reporting entity.

\section{Who are not related parties? (as per IAS-24 of the IFRS)}

The following are deemed not to be related:

- Two entities simply because they have a director or key manager in common.

- Two venturers who share joint control over a joint venture.

- Providers of finance, trade unions, public utilities, and departments and agencies of a government that does not control, jointly control or significantly influence the reporting entity, simply by virtue of their normal dealings with an entity (even though they may affect the freedom of action of an entity or participate in its decision-making process).

\section{Disclosure required (as per IAS-24 of the IFRS)}

Relationships between parents and subsidiaries

Regardless of whether there have been transactions between a parent and a subsidiary, an entity must disclose the name of its parent and, if different, the ultimate controlling party. If neither the entity's parent nor the ultimate controlling party produces financial statements available for public use, the name of the next most senior parent that does so must also be disclosed.

\section{Management compensation}

Disclose key management personnel compensation in total and for each of the following categories:

- Short-term employee benefits

- Post-employment benefits

- Other long-term benefits

- Termination benefits

- Share-based payment benefits 
Key management personnel are those persons having authority and responsibility for planning, directing and controlling the activities of the entity, directly or indirectly, including any directors (whether executive or otherwise) of the entity.

If an entity obtains key management personnel services from a management entity, the entity is not required to disclose the compensation paid or payable by the management entity to the management entity's employees or directors. Instead the entity discloses the amounts incurred by the entity for the provision of key management personnel services that are provided by the separate management entity.

\section{Related party transactions}

If there have been transactions between related parties, disclose the nature of the related party relationship as well as information about the transactions and outstanding balances necessary for an understanding of the potential effect of the relationship on the financial statements. These disclosures would be made separately for each category of related parties and would include:

- The amount of the transactions

- The amount of outstanding balances, including terms and conditions and guarantees

- Provisions for doubtful debts related to the amount of outstanding balances

- Expense recognized during the period in respect of bad or doubtful debts due from related parties.

Examples of the kinds of transactions that are disclosed if they are with a related party:

- Purchases or sales of goods

- Purchases or sales of property and other assets

- Rendering or receiving of services

- Leases

- Transfers of research and development

- Transfers under license agreements 
- Transfers under finance arrangements (including loans and equity contributions in cash or in kind)

- Provision of guarantees or collateral

- Commitments to do something if a particular event occurs or does not occur in the future, including executory contracts (recognized and unrecognized)

- Settlement of liabilities on behalf of the entity or by the entity on behalf of another party.

A statement that related party transactions were made on terms equivalent to those that prevail in arm's-length transactions should be made only if such terms can be substantiated. 